\section{Analysis of geological ochre: its geochemistry, use, and exchange in the US Northern Great Plains}

\author{
Anne Kingery-Schwartz, ${ }^{1}$ \\ Rachel S. Popelka-Filcoff, ${ }^{2}$ \\ David A. Lopez, ${ }^{3}$ Fabien Pottier, ${ }^{4}$ \\ Patrick Hill, ${ }^{5}$ Michael Glascock ${ }^{6}$ \\ ${ }^{1}$ Kingery Conservation LLC, Washington, \\ DC, USA; ${ }^{2}$ School of Chemical and \\ Physical Sciences, Flinders University, \\ Adelaide, South Australia 5001, \\ Australia; ${ }^{3}$ Independent Geological \\ Consultant, Billings, MT, USA; ${ }^{4}$ Centre de \\ Recherche sur la Conservation des \\ Collections, Museum National d'Histoire \\ Naturelle, Paris, France; ${ }^{5}$ Little Big Horn \\ College, Crow Agency, MT; ${ }^{\circ}$ University of \\ Missouri Research Reactor Facility, \\ Columbia, MO, USA
}

\begin{abstract}
Samples of pigments indigenous to the US Northern Great Plains were collected in association with the conservation of a buffalo hide tanned and painted by a Crow Indian(s) in the $19^{\text {th }}$ century, which is now in the collection of the National Museum of American Indian. The pigments were characterised using a series of analytical techniques - some common and others uncommon to the conservation science field, including portable X-ray fluorescence (pXRF), X-ray diffraction (XRD), and instrumental neutron activation analysis (INAA). XRF is not capable of differentiating between various ochre samples due to high detection limits. XRD can detect some matrix minerals in each sample, but these data cannot characterise pigments by original source location. INAA is capable of characterizing ochres from different sources based on trace element geochemistry; however, the large sample size it requires (approximately $100 \mathrm{mg}$ ), makes sampling from objects challenging and therefore makes it difficult to use for technical art history studies that focus on museum objects. INAA is useful if applied to reference materials, such as historic pigments or known sources for historic artistic materials.
\end{abstract}

\section{Introduction}

The study of iron oxide pigments has interested scholars from a range of material culture fields. Diverse scholars such as geologists, archaeologists, historians, and material cul- ture scientists (Figure 1) all encounter collection materials made using iron oxides. Moreover, while the fields of those interested in museum collections are diverse, the ability to characterise iron oxides precisely offers answers to many of these individuals - such as the geological history of a place or information about a culture that settled in a particular time and place. However, fully characterizing these iron oxides is difficult as they are complex heterogeneous mixtures of minerals. This study aims to investigate various analytical techniques that have the potential to characterise them.

\section{Ochre in museum collections} including the National Museum of the American Indian

Today, many museums house painted rawor semi-tanned hide objects - robes, shirts, shields, leggings, moccasins, etc. Pigments that were either mined from the earth or traded are applied to the substrate using water, cactus juice, or hide glue as binders (Ewers, 1939; Moffat et al., 1997; Voget, 2001). In particular, red ochre (iron oxide) and other red pigments, both natural and synthetic, were highly prized by prehistoric and historic Native American cultures (Ewers, 1939; Moffat et al., 1997; Blakeslee, 1976; Brasser, 1982; Bunzel, 1932; Danziger and Hanson, 1979; Fewkes, 1904; Leechman, 1932; Mails, 1996; Mallery, 1886; Morrow, 1975; Vestal, 1952; Wallace, 1934; Wissler, 1910). In addition to written sources, evidence of pigment use remains on the objects themselves. Geological studies suggest ochre was readily available in geographically diverse locations, however, there is also evidence that pigments were part of a complex intertribal trade network that pre-dates contact with Europeans (Blakeslee, 1976).

Pigments in the Northern Great Plains generally fall into two categories: Anglo trade pigments and indigenously produced pigments. However, further research into indigenous pigments suggests some came from intertribal trade rather than local mining and production (Blakeslee, 1976). Therefore, the source of iron oxide pigments and their similarities to similarly colored pigments would give insight into the materials used to decorate these objects and the relation of the objects to each other.

\section{Studies of ochre within the art con- servation field}

While many analytical studies within the conservation field have been conducted on pigments, only a few have focused on pigments used by indigenous cultures of the Americas and even fewer are specific to the Great Plains of North America. The one significant study, conducted by the Canadian Conservation
Correspondence: Anne Kingery-Schwartz, Kingery Conservation LCC, 516 A Street NE, 104 Washington DC 20002, USA

Tel/Fax: + 1.202.355.8664.

E-mail: aekingery@gmail.com

Key words: ochre, INAA, XRF, XRD, Northern Great Plains.

Citation: Kingery A, Popelka-Filcoff RS, Lopez DA, Hill P, Glascock M, 2013. Analysis of geological ochre: its geochemistry, use, and exchange in the US Northern Great Plains. In: RH Tykot (ed.), Proceedings of the $38^{\text {th }}$ International Symposium on Archaeometry - May $10^{\text {th }}-14^{\text {th }} 2010$, Tampa, Florida. Open Journal of Archaeometry 1:e15

Acknowledgments: the University of Missouri Research Reactor Facility (MURR) Archaeometry Lab and staff. National Science Foundation (\#0802757): Michael D. Glascock, P.I. The Andrew W. Mellon Foundation: Marian Kaminitz, Jessica Johnson, Susan Heald, Emily Kaplan. National Museum of American Indian: Jeff Speakman, Rae Beaubien, and Lynn Brostoff. Smithsonian Museum Conservation Institute: Tim McCleary. Little Bighorn College: Putt Thompson. Little Bighorn Trading Post: Jack Bailey, rancher in Montana.

Presented at the $38^{\text {th }}$ International Symposium on Archaeometry - May $10^{\text {th }}-14^{\text {th }} 2010$, Tampa, Florida.

This work is licensed under a Creative Commons Attribution 3.0 License (by-nc 3.0).

(C) Copyright A. Kingery-Schwartz et al., 2013 Licensee PAGEPress, Italy

Open Journal of Archaeometry 2013; 1:e15 doi:10.4081/arc.2013.e15

Institute, reviewed the historical literature and compared the information of results from portable X-ray fluorescence (pXRF), X-ray diffraction (XRD), and Fourier transform infrared spectroscopy analyses (Miller, 1986). This study provides a good timeline regarding the introduction of trade pigments. However, this study did not characterise the iron oxide based pigments in any specific way. Thus no conclusions could be drawn about the origin of these pigments. Were they trade pigments, were they locally mined by the tribes of the Great Plains, or were they traded from non-local tribes?

\section{Materials and Methods}

Building up a reference library of deposits of iron oxide pigments that might possibly have been mined by native artists across the continent would illuminate the use and history of the pigments used on historic objects made on the Great Plains. Chemical characterization of 
samples from known pigment mining areas will establish a foundation for understanding the sources of iron oxide pigments.

Research into various analytical techniques was conducted to determine if any held potential to gain a better understanding of iron oxide materials used for pigments. For this study, techniques traditionally used for analysing museum collections were re-examined, and techniques not consistently used by the conservation science field were also considered. The three techniques compared are pXRF, XRD, and instrumental neutron activation analysis (INAA). The first two are techniques require little or no sample, so they are utilised frequently by the conservation science field. In the case of pXRF, the analysis of the object can be accomplished by holding the instrument within a few millimeters of the surface of the object; therefore no sample is required. For XRD a sample around $1 \mathrm{mg}$ must be removed from the object, but the sample is so minute, the damage is negligible. While these first two techniques and the required sampling are acceptable to the museum personnel, many Native American cultures do not approve; they have a different perspective of the objects and their care and preservation. Therefore, all analytical techniques must be discussed with the specific culture from which the materials originated. The third technique, INAA, investigated in this study is not widely used by the conservation field, because of the large sample required. INAA requires samples $50-100 \mathrm{mg}$ in size. The heterogeneous nature of iron oxides complicates their analysis, and a small sample size, such as those required by XRD, may not fully describe all the components of the mixture. Since knowing the source of the iron oxide pigment would offer great insight into the manufacture of these objects, this study was designed to determine if a combination of these techniques could hold promise to characterise in detail iron oxides used on objects. Because of the large sample size required by INAA, no samples from objects were used. Authors collected samples both from geological sources and from native artists who purportedly collected their own pigments from geological sources. Of those collected directly from geological sources, two main formations were sampled: the Kootenai and Chugwater. The Chugwater Formation is of Lower Triassic age and rests on an erosional surface cut across rocks of Permian age mostly of the Phosphoria Formation. The Chugwater is characterised by brick-red sandstones and mudstones deposited mainly in fluvial environments on a broad coastal plain (Figures 2 and 3). The Kootenai Formation (referred to as the Cloverly Formation in Wyoming) is of Lower Cretaceous age and was deposited on an erosional surface cut into the Jurassic Morrison Formation. The lavender, maroon, and red mudstones were deposited by streams flowing across a coastal plain that bordered a Cretaceous seaway that extended from Texas to Alaska. The bright colors of the mudstones in these formations resulted from the oxidizing conditions that existed during deposition of these terrestrial deposits. A smaller set of samples were taken from a colourful deposit that oral history holds is a traditional site for contemporary artists to gather pigments (Deer Medicine Rock samples). Of those pigments collected by indigenous artists, some were collected from a trading post where a Cheyenne artist sold them (Trade Pigment samples in Table 1). Another set were part of a paint kit made by a Crow artist (Lame Deer samples in Table 1). Each sample was analysed by XRD and INAA. The geological samples were analysed with XRF.

\section{Instrumental parameters}

XRD: instrument: Rigaku D/Max Rapid Micro X-ray Diffractometer, Power: 46 kV; 39 $\mathrm{mA} ; 1.79 \mathrm{~kW}$, Radiation: Chromium Ka, Goniometer, ki: fixed at 45?, Goniometer, speed: $1 \%$ sec., Omega oscillation: fixed at 0 degree, Phi oscillations: Spin (1 degree/second), Exposure time: 30 min, Collimator: 0.8 $\mathrm{mm}$.

XRF: Bruker Handheld Portable XRF Analyzer, TRACER-III-V, Detector: Peltier cooled Ag-free SiPIN, with resolution $\sim 195 \mathrm{eV}$ @Mn, Baud Rate: 57,600, Power: 40 kV; 3 A, Filter: $12 \mathrm{mil} \mathrm{Al}+1 \mathrm{mil} \mathrm{Ti}+1 \mathrm{mil} \mathrm{Cu}, 60 \mathrm{sec}$ count.

INAA instrumental parameters: the NAA sample preparation and analysis followed standard procedures described elsewhere (Popelka-Filcoff et al., 2008).

The INAA analysis followed standard geochemical procedures developed by Glascock (1992). For the short counts, about $60 \mathrm{mg}$ of sample was irradiated for $5 \mathrm{~s}$ at a thermal flux of approximately $8.0 \times 10^{13}$ neutrons $\mathrm{cm}^{-2} \mathrm{~s}^{-1}$. After a decay of $25 \mathrm{~min}$, the samples were counted for $720 \mathrm{~s}$. For the mid-count and longcount measurements, about $60 \mathrm{mg}$ of sample were sealed in high purity quartz vials and irradiated for $24 \mathrm{~h}$ at a thermal neutron flux of approximately $5.2 \times 10^{13}$ neutrons $\mathrm{cm}^{-2} \mathrm{~s}^{-1}$. After a decay period of 7 days, the mid count data was acquired for $2000 \mathrm{~s}$. After decay of an additional 3 weeks, the long count data were acquired for $10,000 \mathrm{~s}$. The comparator standards used in the INAA measurements were NIST SRM 1633a (fly ash) and SRM 688 (basalt), and the quality control standards were NIST SRM 278 (Obsidian Rock) and Ohio red clay (Glascock, 1992). The principal component (PCA) and canonical discriminant analyses (CDA) were performed on statistical routines written in GAUSS language and described elsewhere (Glascock, 1992; Neff , 1994; Popelka-Filcoff et al., 2007).

\section{Results and Discussion}

\section{XRD and pXRF results and discus-}

\section{sion}

Results are summarised in Table 1. pXRF allows the detection of most elements in the periodic table with atomic numbers above sodium. In the case of mineral pigments, the elements needed to differentiate sources occur in the transition elements and higher. Therefore, pXRF presents an excellent qualitative technique for identifying pigments without taking a sample. In the conservation field, having to remove even the smallest sample from an object is seen as destructive - even if the sample is not destroyed during analysis.

For all the geological samples analysed with pXRF, iron was the main element detected. In some cases minor elements such as calcium, strontium, and lead were found which typically varied between the sample sites. Due to the differing shapes of the pigments, thickness of pigment layers and other parameters, the technique is qualitative rather than quantitative. Another technique, capable of more quantitative results was necessary to characterise the sources more fully.

XRD allows for the detection of crystallised but not amorphous particles; the results must be interpreted as the crystalline signature of the sample, not as an absolute composition analysis. XRD cannot determine the nature of amorphous phases. The diffraction intensities of the different species depend on the size, shape, and nature of the crystalline particles, so cannot be used for quantification. For instance, a very strong signal can be emitted by a minor phase. For this reason, even semiquantification (determination of minor versus major phases) is complicated. However, the results are fairly consistent and provide a good tool to compare the samples from a qualitative point of view.

The only iron oxide characterised in most of the samples was hematite, although sometimes goethite was also detected (Table 1). Goethite is not highly crystallised, which makes it difficult to detect by XRD. Since these different iron oxides do not always have the same crystallinity level, depending on the sample, quantitative comparison between samples is impossible. Thus, the presence, identity, and quantity of these iron oxides in a sample cannot be used for differentiating between samples. In addition to the iron oxides detected in each sample, matrix minerals were also detected. During this study it was not known what matrix minerals were specific for each geological formation, but some differences were detected between samples (presence or not of gypsum, calcite or dolomite). It is possible that these matrix minerals could be used to distin- 
guish some of the samples from each other, but results suggest this is not enough to specifically determine if an iron oxide mixture is from a specific site.

\section{Instrumental neutron activation analysis results and discussion}

Complete elemental data from neutron activation analysis for this study is posted at the University of Missouri Archaeometry web site (http://archaeometry.missouri.edu/).

Because of the ambiguity of the results of pXRF and XRD, INAA offered a technique that would further differentiate samples by elemen- tal geochemical analysis. Geochemical analysis of the sources in the northern Great Plains was undertaken by NAA to characterise these sources.

Once the data were analysed by PCA, the following elements were identified as having greater variance in the data set: $\mathrm{Cs}, \mathrm{La}, \mathrm{Mn}, \mathrm{Rb}$, $\mathrm{Sr}$, Th, V and Zn. Plots of the geological data in elemental space also indicate that the three regions can be differentiated. In general, the elements that provided the most variance in the Northern Great Plains data set were: Ba, $\mathrm{Co}, \mathrm{Mn}, \mathrm{Sr}$, Th and $\mathrm{Zn}$. This study is the first to construct a database of ochre and pigments from this geographic region, as well as the first to study iron pigments from related Native American objects.

Through several analyses of grouping of the samples, the data suggest that the samples can be divided based on geological origin as well as source. The first analysis classified the artifacts based on geological information in four groups: Kootenai, Chugwater, Lame Deer, and trade pigments. An example plot of this is Figure $4\left(\log _{10}[\mathrm{Cr} / \mathrm{Fe}]\right.$ vs $\left.\log _{10}[\mathrm{Mn} / \mathrm{Fe}]\right)$. The Kootenai and Chugwater samples do have some association, which reflects their close geographic relationship on the Crow Reservation. The trade pigment samples form two very tightly formed and distinct groups,

Table 1. Results of X-ray fluorescence and diffraction analysis.

\begin{tabular}{|c|c|c|c|c|c|c|c|}
\hline Source & $\begin{array}{l}\text { Geological } \\
\text { formation }\end{array}$ & Colour & $\begin{array}{l}\text { Iron } \\
\text { oxide }\end{array}$ & $\begin{array}{l}\text { Possible } \\
\text { iron oxide }\end{array}$ & $\begin{array}{l}\text { Matrix } \\
\text { minerals }\end{array}$ & $\begin{array}{l}\text { Possible } \\
\text { identifications }\end{array}$ & $\begin{array}{l}\text { Elements } \\
\text { detected with XRF }\end{array}$ \\
\hline $\begin{array}{l}\text { Crow Reservation, } \\
\text { East of St. Xavier, MT }\end{array}$ & Kootenai & Red-Purple & Hematite & Goethite & $\begin{array}{l}\text { Quartz, } \\
\text { Kaolinite, } \\
\text { Other clays }\end{array}$ & $\begin{array}{l}\text { Muscovite, } \\
\text { Kornelite, } \\
\text { Nacrite, } \\
\text { Halloysite }\end{array}$ & $\mathrm{Fe}, \mathrm{Sr}, \mathrm{Rb}, \mathrm{Ti}$ (minor) \\
\hline Red Dome, MT & Kootenai & Dark red & & Hematite & $\begin{array}{l}\text { Quartz, } \\
\text { Calcite, } \\
\text { Dolomite, Clays }\end{array}$ & $\begin{array}{l}\text { Muscovite, } \\
\text { Kornelite }\end{array}$ & Not analysed \\
\hline Blue Water, MT & Kootenai & Red & Hematite & & $\begin{array}{l}\text { Quartz, } \\
\text { Calcite, } \\
\text { Clays }\end{array}$ & $\begin{array}{l}\text { Muscovite, } \\
\text { Kornelite }\end{array}$ & Not analysed \\
\hline $\begin{array}{l}\text { Crow Reservation, } \\
\text { East of St. Xavier, MT }\end{array}$ & Chugwater & Red-orange & Hematite & & $\begin{array}{l}\text { Quartz, } \\
\text { Dolomite, } \\
\text { Clays }\end{array}$ & $\begin{array}{l}\text { Muscovite, } \\
\text { Kornelite, } \\
\text { Bernalite }\end{array}$ & Not analysed \\
\hline Red Dome, MT & Chugwater & Red-orange & Hematite & & $\begin{array}{l}\text { Quartz, } \\
\text { Dolomite, } \\
\text { Calcite, } \\
\text { Clays }\end{array}$ & $\begin{array}{l}\text { Microcline, } \\
\text { Muscovite, } \\
\text { Kornelite }\end{array}$ & Not analysed \\
\hline Bear Canyon West, MT & Chugwater & Red-orange & & Hematite & $\begin{array}{l}\text { Quartz, } \\
\text { Dolomite, } \\
\text { Clays }\end{array}$ & $\begin{array}{l}\text { Microcline, } \\
\text { Muscovite, } \\
\text { Kornelite }\end{array}$ & Not analysed \\
\hline $\begin{array}{l}\text { Deer Medicine Rock, } \\
\text { Jack Bailey Ranch, } \\
6 \text { miles north } \\
\text { of Lame Deer, MT }\end{array}$ & Unknown & Red & Hematite & Goethite & $\begin{array}{l}\text { Quartz, } \\
\text { Gypsum, } \\
\text { Calcite, } \\
\text { Kaolinite, } \\
\text { Other clays }\end{array}$ & $\begin{array}{l}\text { Muscovite, } \\
\text { Kornelite, } \\
\text { Orthoclase }\end{array}$ & $\mathrm{Fe}$, no $\mathrm{Ca}$ \\
\hline $\begin{array}{l}8 \text { miles north } \\
\text { of Lame Deer, MT, } \\
\text { From artist's pigment set }\end{array}$ & Unknown & Red-orange & & Hematite & $\begin{array}{l}\text { Quartz, } \\
\text { Calcite, } \\
\text { Dolomite, } \\
\text { Cays }\end{array}$ & $\begin{array}{l}\text { Kaolinite, } \\
\text { Muscovite, } \\
\text { Kornelite }\end{array}$ & $\mathrm{Ca}$ \\
\hline $\begin{array}{l}\text { Trade pigment, } \\
\text { purportedly } \\
\text { collected from } \\
\text { a geological source }\end{array}$ & Unknown & Red & Hematite & & $\begin{array}{l}\text { Quartz, } \\
\text { Calcite, } \\
\text { Dolomite, } \\
\text { Clays }\end{array}$ & $\begin{array}{l}\text { Muscovite, } \\
\text { Kornelite, } \\
\text { Bermalite }\end{array}$ & $\mathrm{Fe}$ \\
\hline $\begin{array}{l}\text { Trade pigment, } \\
\text { purportedly from } \\
\text { a geological source }\end{array}$ & Unknown & Red-brown & Hematite & & $\begin{array}{l}\text { Quartz, } \\
\text { Calcite, } \\
\text { Dolomite, } \\
\text { Clays }\end{array}$ & $\begin{array}{l}\text { Kaolinite, } \\
\text { Muscovite, } \\
\text { Kornelite }\end{array}$ & Not analysed \\
\hline $\begin{array}{l}\text { Trade pigment, } \\
\text { purportedly from } \\
\text { a geological source }\end{array}$ & Unknown & Orange & Hematite & & $\begin{array}{l}\text { Quartz, } \\
\text { Calcite, } \\
\text { Dolomite, } \\
\text { Clays }\end{array}$ & $\begin{array}{l}\text { Kaolinite, } \\
\text { Muscovite, } \\
\text { Microcline, } \\
\text { Kornelite, } \\
\text { Bernalite }\end{array}$ & Not analysed \\
\hline
\end{tabular}


one of which may be related to the Chugwater samples. The Lame Deer samples are the most diverse of the sample set. Kootenai and Chugwater are two different geological formations found on the Crow Reservation from different geological time periods. The Lame Deer source has some samples clustered tightly together, but three samples (KPF 13-15) were consistent outliers within the data set. These samples, from the Jack Bailey Ranch (Deer Medicine Rock in Table 1), are clearly geochemically different than other samples in the data set. It is known that this source is used in modern times for pigment collection, but is not related to any of the other sources or regions in this study. As knowledge is passed down orally through Crow generations, it is likely those individuals gathering pigments here were shown this deposit by their ancestors.

A subsequent canonical discriminant analysis shows that the three geological groups can be clearly defined although one of the initial assumptions of the CDA analysis is previously defined groups.

An additional analysis was undertaken of the same data set using source information from the samples. Figure $5-\log _{10}[\mathrm{U} / \mathrm{Fe}] v s$ $\log _{10}[\mathrm{Zn} / \mathrm{Fe}]$ - shows one of the clearest relationships between the groups. In general, samples from the Crow Reservation are in one tight group with a few outliers. Lame Deer samples are also one tight group, but samples KPF 13-15 are consistent outliers from the main cluster of samples. Red Dome samples consistently form a close group, as do Blue Water samples. The pigment subset of samples reliably group into two tight clusters. At this point, it is difficult to attribute these trade pigment samples (KPF 16-23 and KPF 24-31) to a particular geological source, but the two most likely are related to Crow Reservation and Lame Deer. However, these samples may be related to other sources that have yet to be sampled. At this point an exact location cannot be identified for samples KPF 16-23, but they are most likely geochemically related to either the Kootenai or Chugwater formations.

\section{Conclusions}

This study demonstrated a combination of analytical methodologies used to analyse ochre and iron-based pigments from the Northern Great Plains region. pXRF provided initial identification of the elements present. XRD provided qualitative information on the mineralogy of the samples, but could not differentiate between original sources. Results clearly illustrated that geochemical analysis by INAA with multivariate statistics has the potential to differentiate between sources of iron oxides; however, the data gathered by XRD and XRF were not specific enough to help draw correlations between the INAA data and the iron oxides found on objects. XRF does not give information about the minor elements in a sample, nor does it give an idea of concentration of various elements. Therefore, all mixtures containing iron and manganese will look similar when analysed by XRF. XRD give both elemental and crystallographic information; however, its inability to give information about the percentage of the various minerals makes it difficult to relate to INAA. However, the combination of methodologies provides a more complete picture for these samples. A possible path for future study could be scanning electron microscopy (SEM) with energy dispersive spectroscopy (EDAX). The electron maps give some information about the location concentration of elements.

Although considered more destructive than other analytical techniques in conservation

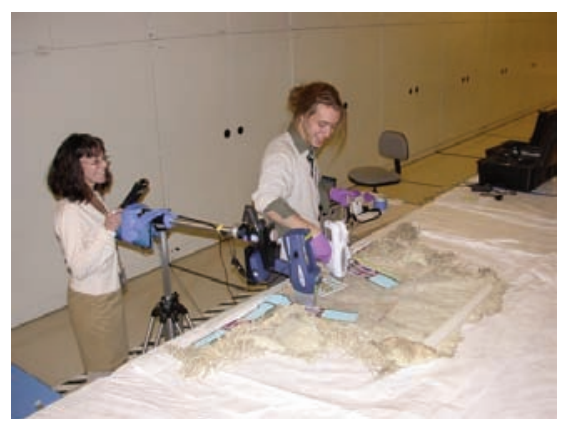

Figure 1. Lynn Brostoff (left) and Fabien Pottier (right) using X-ray fluorescence to analyse what may be natively mined pigments on a Crow warrior's shirt. They are using two different $\mathrm{X}$-ray fluorescence units to compare results.

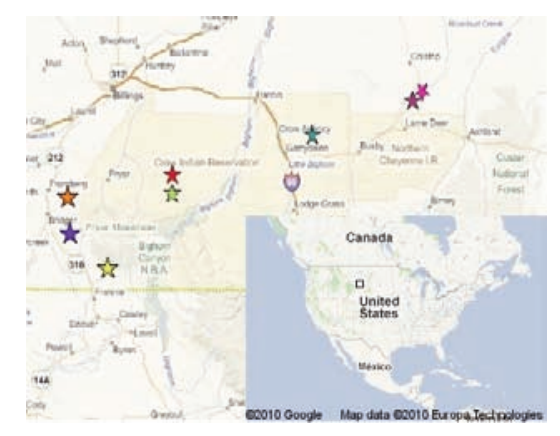

3Figure 2. Map of western part of Crow reservation. Green, St. Xavier Kootenai formation; red, St. Xavier Chugwater formation; teal, Custer Battlefield trading post; purple, Deer Medicine Rock; pink, site where paint kit ochre pigments were mined; yellow, Bear Canyon; blue, Red Dome; orange, Blue Water. science, INAA can provide valuable data on source origin on samples and objects if used with care. These first samples provide a beginning of a database for the region, and a comparison database for future studies. Future studies in this area can include characterization of other known sources in the region. In

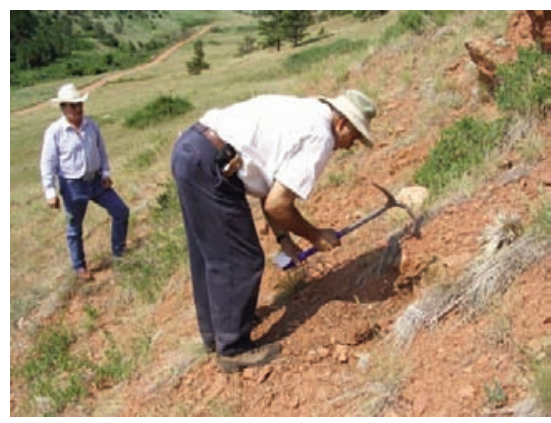

Figure 3. Dr. David Lopez takes a sample from the Chugwater formation as Burton Pretty on top, who was then a member of the Oil and Gas Committee of the Crow Tribe, looks on.

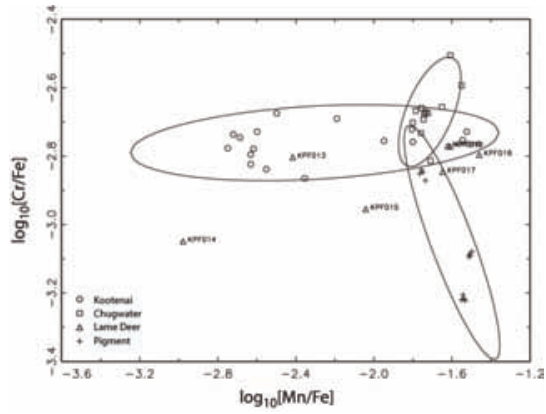

Figure 4. $\log _{10}[\mathrm{Cr} / \mathrm{Fe}]$ vs $\log _{10}[\mathrm{Mn} / \mathrm{Fe}]$ demonstrating groups based on geological origin. Confidence ellipses are $\mathbf{9 0 \%}$.

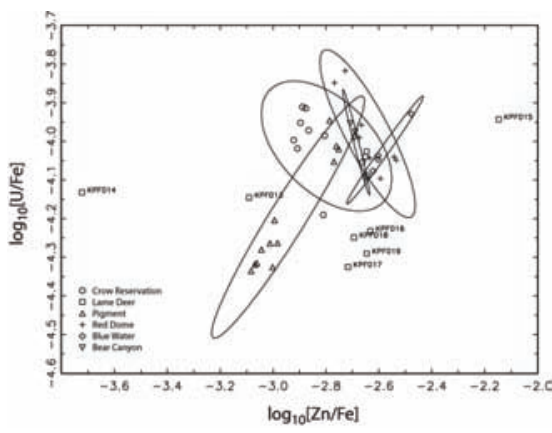

Figure 5. $\log _{10}[\mathrm{U} / \mathrm{Fe}]$ vs $\log _{10}[\mathrm{Zn} / \mathrm{Fe}]$ demonstrating groups based on source information. Confidence ellipses are $\mathbf{9 0 \%}$. 
addition, more samples from artifacts could be compared to known source samples, to identify possible connections between objects and original sources of pigment material. In addition, the heterogeneous nature of iron oxides makes any type of analysis with small sample size requirements a non-ideal choice to study these complex mixtures.

However, thought must be given about how the large sample size required by INAA can be reconciled with the ethics of the conservation field.

\section{References}

Blakeslee D, 1976. The Plains interband trade system an ethnohistoric and archeological investigation. University of Wisconsin ed., Milwaukee.

Brasser T, 1982. Decorated tipis: what their markings mean. Canadian Heritage 38:630 .

Bunzel R, 1932. Zuñi Katcinas. Annual Report for the Bureau of Ethnology 47:837-1086.

Ewers JC, 1939. Plains indian painting: a description of an aboriginal American art. Stanford University Press, Sanford, CA, pp 4-6.

Danziger CS, Hanson J, 1979. The conservation of a Tlingit totem pole. In: Preprints of papers presented at the seventh annual meeting, Toronto, Canada, 30-31 May and 1 June 1979. American Institute for Conservation, Washington, pp 21-4.

Fewkes JW, 1904. Two summers' work in Pueblo ruins. Annual Report for the Bureau of Ethnology 22:3-19.

Glascock M, 1992. Characterization of archaeological ceramics at MURR by neutron activation analysis and multivariate statistics. In: H. Neff (ed.) Chemical characterization of ceramic pastes in archaeology. Prehistory Press, Madison, pp 11-26.

Leechman D, 1932. Native paints of the Canadian West coast. Technical Studies in the Field of the Fine Arts 5:203-8.

Mails T, 1996. The mystic warriors of the plains: the culture, arts, crafts and religion of the plains Indians. Marlowe and Company, New York, pp 261-84.

Mallery G, 1886. On the pictographs of North American Indians. Annual Report for the Bureau of Ethnology 4:213-56.

Miller J, 1986. Analysis of paints used by Canadian native cultures: a project at the Canadian Conservation Institute. Canadian Conservation Institute, Ottawa, pp 137-41.

Moffat EA, Sirois J, Miller J, 1997. Analysis of the paints used to decorate Northern Plains hide artifacts during the nineteenth and early twentieth centuries. Journal of the Canadian Association for Conservation 22:39-52.

Morrow M, 1975. Indian rawhide: an American folk art. University of Oklahoma Press, Norman, OK, pp 32-7.

Neff H, 1994. RQ-mode principal components analysis of ceramic compositional data. Archaeometry 36:115-30.

Popelka-Filcoff RS, Miksa E, Robertson JD, Glascock MD, Wallace H, 2008. Elemental analysis and characterization of ochre sources from Southern Arizona. J Archaeol Sci 35:752-62.

Popelka-Filcoff RS, Robertson JD, Glascock MD, Descantes C, 2007. Trace element characterization of ochre from geological sources. J Radioanal Nucl Ch 272:17-27.

Vestal P, 1952. Ethnobotany of the Ramah Navaho. Papers of the Peabody Museum of American Archaeology and Ethnology, Harvard University, Cambridge, MA.

Voget FW, 2001. Crow. Smithsonian Institution ed., Washington, p 700.

Wallace WS, 1934. Documents relating to the North West company. The Champlain Society, Toronto.

Wissler C, 1910. Material culture of the blackfoot Indians. Anthropological Papers of the American Museum of Natural History, pp 133-5. 